\title{
ANALISA KEGAGALAN KOMUNIKASI POLITIK DALAM PILKADA SERENTAK 2015 DI KABUPATEN SLEMAN \\ (STUDI KASUS PDI PERJUANGAN)
}

\author{
Oleh: \\ Choirul Fajri, dan Dani Fadillah \\ E-mail: choirul.fajri@comm.uad.ac.id,daniuad@yahoo.co.id \\ Program Studi Ilmu Komunikasi \\ Universitas Ahmad Dahlan
}

\begin{abstract}
Abstrak
Penelitian ini bertujuan untuk mengevaluasi kegagalan proses komunikasi dalam sebuah dinamika politik dalam konteks Pilkada. Pada pemilihan kepala daerah 2015 lalu di Sleman DIY, PDIP Perjuangan yang merupakan partai besar, dengan basis massa yang banyak, dan merupakan partai pemenang pemilu ternyata mengalami kekalahan.

Penelitian ini dilaksanakan dengan menggunakan pendekatan deskriptif kualitatif. Tipe dari penelitian ini adalah melakukan penelaahan secara mendalam terhadap strategi politik yang dilakukan oleh PDI Perjuangan serta strategi yang dilakukan oleh rival politiknya, sehingga menyebabkan kegagalan kemenangan pasangan calon yang disusng oleh PDI Perjuangan. Beberapa aktivitas dilaksanakan seperti melakukan wawancara, mengumpulkan data dan mengkaji pemberitaan-pemberitaan yang ada.

Hasil dari penelitian ini menunjukkan adanya kegagalan komunikasi politik PDIP dalam Pilkada Serentak di Sleman 2015, hal tersebut karena PDIP kurang mengintegrasikan ranah komunikasi internalnya, tidak memainkan isu-isu untuk menciptakan opini publik, dan mengelola media komunikasi dengan baik.
\end{abstract}

Kata Kunci: Komunikasi Politik, Pilkada, dan PDI Perjuangan.

\begin{abstract}
This study aims to evaluate the failure of the communication process in a political dynamics in the context of Regional Head Election. In the election of regional head in 2015 and then in Sleman DIY, PDIP Perjuangan which is a big party, and having many participants, and also being the winner of the election turned out defeat.

This research was conducted by using qualitative descriptive approach. The type of this study is to conduct an in-depth review of the political strategies undertaken by the PDI-P and the strategy undertaken by political rivals, thus causing the failure of the victory of candidate pairs from PDI$P$. Some activities are carried out such as conducting interviews, collecting data and reviewing existing reports.

The results of this study indicate the failure of PDIP political communication in Sergeant Elections in Sleman 2015, it is because PDIP lacks of integrally internal communication domain, does not play issues to create public opinion, and manage communication media well.
\end{abstract}

Keywords: Political communication, Pilkada, PDI perjuangan. 


\section{A. PENDAHULUAN}

Gairah politik di tingkat lokal belakangan semakin marak seiring dengan gelaran Pilkada yang telah direncanakan. Pilkada sendiri dijadwalkan sebagai ajang eksperimentasi demokrasi, semenjak lahirnya UU No. 32 Tahun 2004 yang merevisi UU No. 22 Tahun 1999 pada medio September 2004 lalu. Hadirnya naskah undang-undang tersebut memang "memaksa" seluruh propinsi dan seluruh kabupaten serta kota di Indonesia untuk mau tidak mau menggelar hajatan Pilkada di daerahnya secara langsung. Pemilihan kepala daerah secara langsung langsung, tujuannya adalah ingin mengembalikan kesadaran berdemokrasi ini pada hakikat yang sesungguhnya. Pilkada langsung memberikan hak penuh kepada rakyat untuk menentukan siapa yang berhak untuk dijadikan pemimpin, yang tentu diharapkan dapat menjadi pelayan masyarakat yang baik, tidak hanya menjadi penguasa semata.

Pemilihan kepala daerah secara langsung merupakan salah satu hal baru yang terdapat pasca gerakan reformasi tahun 1998. Sebelumnya kepala daerah dipilih oleh anggota DPRD, namun arus demokratisasi menghendaki adanya perubahan sehingga pada tahun 2004 melalui Undang-Undang Nomor 32 tahun 2004 tentang Pemerintahan Daerah (UU Pemda) diberlakukanlah pemilihan kepala daerah secara langsung.

Dengan adanya kebijakan pemilihan kepala daerah secara langsung, oleh rakyat membuat Pilkada menjadi arena politik yang keras, antar partai politik saling mengeluarkan strategi komunikasinya masing-masing baik di internal partai, masyarakat, hingga pada saingan politiknya. Dimana inti dari komunikasi politik yang dibangun itu adalah kemenangan politik untuk menjadi kepala daerah.

Adalah Partai Demokrasi Indonesia Perjuangan (PDIP), partai pemenang pemilu 2014 yang sekaligus mengantarkan salah satu kader terbaiknya menjadi orang nomor satu di Indonesia, turut mengawal salah satu kader terbaiknya di Daerah Istimewa Yogyakarta (DIY) untuk menjadi Kepala Daerah di Kabupaten Sleman.

Di dalam konteks DIY khususnya di Kabupaten Sleman, PDIP memiliki track record yang bagus. Pada tahun 2000 tahun terakhir PDIP berhasil mengawal kadernya, Ibnu Subiyanto, untuk duduk menjadi orang nomor satu di Kabupaten Sleman, kemenangan serupa terulang pada tahun 2005. Pada tahun 2010 PDIP juga berhasil mengusung Yuni Satia Rahayu duduk di kursi pemerintahan Kabupaten Sleman mendampingi Sri Pirnomo dari PAN. Di level DIY pun PDIP memiliki sumber daya yang bagus, bahkan memiliki kedekatan emosional dengan sebuah surat kabar berpengaruh di DIY. Akan tetapi pada tahun 2015, seluruh calon yang diusung oleh PDIP di DIY gagal untuk menjadi kepala daerah, tradisi yang telah terbangun dengan sangat baik sejak era pilkada langsung dilaksanakan terputus. Hal ini lah yang mendorong peneliti, untuk meneliti hal-hal yang menyebabkan kegagalan komunikasi politik PDIP dalam pilkada serentak tahun 2015 di Kabupaten Sleman.

\section{B. TINJAUAN PUSTAKA}

\section{Persuasif}

Suatu kegiatan yang selalu ada dalam dunia perpolitikan, adalah persuasif politik. Persuasif merupakan sifat dari persuasi, sementara dalam kamus ilmiah populer persuasi 
adalah tenaga meyakinkan, bujukan, bentuk karangan yang menguraikan suatu masalah atau keadaan yang dibuktikan dengan data-data dan fakta-fakta yang bertujuan membujuk atau mengajak atau mempengaruhi pembaca, sehingga mereka mau mengikuti atau melakukan sebagaimana yang diharapkan sang komunikator, sementara itu untuk pengertian persuasif sendiri adalah meyakinkan, lunak, tanpa kekerasan (Yacub, 2001: 592-593).

Dan Nimmo (1993, 122-123), menyebutkan bahwa persuasif adalah komunikasi yang bertujuan atau berkepentingan. Tujuan utama dalam persuasif adalah untuk menimbulkan perasaan responsif pada orang lain (dalam dunia politik maka komunikan atau masyarakat). Ada tiga pemahaman tentang proses persuasif. Pertama, persuasi biasanya melibatkan tujuan, suatu usaha komunikator untuk mencapai tujuan melalui pembicaaan. Kedua, persuasif itu bersifat dialektis. Ketiga, memiliki bentuk tanggapan.

Jadi dapat disimpulkan bahwa persuasif politik adalah suatu ajakan, bujukan, rayuan, dengan bentuk tanpa kekerasan yang dilakukan oleh para komunikator politik kepada masyarakat sebagai komunikan dengan tujuan agar masyarakat dapat memberikan dukungan, respon, simpati terhadap dirinya dalam hal kekuasaan dalam suatu negara.

Dalam kehidupan yang senyatanya, persuasif politik lebih sering kita temui ketika menjelang suatu pemilihan umum, dari tingkat dari yang paling dasar sampai tingkat yang paling tinggi dari suatu negara. Cangara (2011, 267-268), menyebutkan bahwa dalam penyusunan pesan politik dalam sebuah komunikasi persuasif ada beberapa teknik yang digunakan, antara lain:

1. Fear Appeal, berarti bagaimana seorang komunikator politik menyusun suatu pesan persuasif yang mengandung unsur memberikan ketakutan kepada komunikan. Biasanya persuasif ini dilakukan oleh komunikan yang sudah memiliki kekuasaan di suatu tempat.

2. Emotional appeal, unsur utama dari teknik ini adalah emosi. Jadi pesan persuasif politik dirangkai sedemikian rupa sehingga dapat menggugah atau menggejolkkan emosi komunikan, misalnya dengan cara mengungkapkan masalah agama, etnis, kesenjangan ekonomi yang sedang terjadi, diskriminasi kaum minoritas dan lain sebagainya.

3. Reward appeal, yatu penyusunan yang penuh akan janji-janji yang disampaikan oleh komunikato, dengan janji masyarakat akan lebih percaya terhadap visi-misi yang disampaikan oleh komunikator.

4. Motivational appeal, teknik ini lebih menekankan bagiamana seorang politikus memberikan dorongan secara interal psikologis kepada masyarakat, bukan pada janji-janji sehingga masyarakat dapat mengikuti pesan-pesan yang disampaikan.

5. Humorius appeal, teknik yang terakhir ini lebih mementingkan bagaimana suatu pesan persuasif disusun sehingga tidak menimbulkan "kejenuhan" pada masyarakat. Karena humor, ringan, enak, menyegarkan akan lebih mudah diterima dibandingkan pesan-pesan yang sangat serius.

Cangara (2011, 270) menambahkan bahwa pesan-pesan yang disusun menggunakan teknik-teknik yang disebutkan di atas akan efektif jika disampaikan dengan racikan propaganda di dalamnya. Propaganda dapat dikatakan sebagai bentuk persuasi yang sangat populer di dunia politik. Secara bahasa propaganda diambil dari kata 
propagare yang berarti "mengembangkan" atau "memekarkan". Dimana secara istilah artinya adalah rangkaian pesan yang bertujuan untuk mempengaruhi pendapat dan kelakuan masyarakat atau sekelompok orang.

Propaganda tidak menyampaikan informasi secara obyektif, tetapi memberikan informasi yang dirancang untuk memengaruhi pihak yang mendengar atau melihatnya. Cangara menyebutkan bahwa propaganda adalah suatu kegiatan komunikasi yang erat kaitannya dengan persuasi. Propaganda diartikan sebagai proses diseminasi informasi untuk mempengaruhi sikap dan tingkah laku seseorang atau kelompok masyarakat dengan motif indoktrinasi ideologi.

Sedangkan Yacub (2001, 326-327) menyebutkan bahwa propaganda disebutkan sebagai gerakan atau upaya perluasan pengaruh, usaha untuk memanipulasi persepsi (emosi dibangkitkan dan perepecahan-perpecahan soal disarankan, padahal mungkin antara persoalan dan pemecahannya tidak ada hubungannya.

Propaganda kadang menyampaikan pesan yang benar, namun seringkali menyesatkan dimana umumnya isi propaganda hanya menyampaikan fakta-fakta pilihan yang dapat menghasilkan pengaruh tertentu, atau lebih menghasilkan reaksi emosional daripada reaksi rasional. Tujuannya adalah untuk mengubah pikiran kognitif narasi subjek dalam kelompok sasaran untuk kepentingan tertentu dan memanipulasi alam pikiran atau kognisi, serta memengaruhi langsung perilaku agar memberikan respon sesuai yang dikehendaki pelaku propaganda. Sebagai komunikasi satu ke banyak orang, propaganda memisahkan komunikator dari komunikannya.

Komunikator dalam propaganda sebenarnya merupakan wakil dari organisasi yang berusaha melakukan pengontrolan terhadap masyarakat komunikannya. Sehingga dapat disimpulkan, komunikator dalam propaganda adalah seorang yang ahli dalam teknik penguasaan atau kontrol sosial. Dengan berbagai macam teknis, setiap pemilik kepentingan politik harus mempergunakan propaganda sebagai suatu mekanisme alat kontrol sosial.

\section{METODE PENELITIAN}

Tipe dari penelitian ini adalah penelitian lapangan. Penelitian ini mempelajari konsep dan implementasi sebuah pesan dalam komunikasi politik oleh sebuah kekuatan politik. Untuk memperkaya dan mempertajam analisis, pendekatan perbandingan model komunikasi politik yang dilakukan oleh lawan politik obyek utama dalam penelitian ini (PDIP) juga akan dijabarkan.

Penelitian ini dilaksanakan dengan menggunakan pendekatan deskriptif kualitatif. Penelitian ini mengambil lokasi di Kabupaten Sleman sebagai tempat utama untuk mengumpulkan data. Berbagai aktivitas dilakukan dalam metode ini, untuk mendapatkan data yang relevan. Mengingat penelitian ini adalah penelitian kualitatif, maka peneliti berusaha semaksimal mungkin untuk mendapatkan data yang mendalan, berdasarkan dengan urutan waktu/peristiwa yang terjadi.

Dalam penelitian ini data yang dikumpulkan antara lain melalui rekaman arsip, wawancara, dan observasi langsung. Peneliti akan mewawancarai informan yang dapat mendukung rumusan masalah diantaranya adalah Pimpinan dan pengurus Partai dan Tim 
Sukses kubu PDIP. Serta melakukan wawancara dan pengumpulan data dari kubu lawan politik PDIP

Penelitian kemudian mengkaji ulang data-data yang sudah didapatkan, dengan penyesuaian-penyesuaian dari keseluruahn data, baik dari wawancara, dokumentasi dan observasi langsung, agar sinkronisasi data ditemukan dan memepermudah pelaksanaan penelitian hingga pada tahap pelaporan.

\section{PEMBAHASAN}

\section{Pilkada Serentak dan Ketidaktercapain Target PDIP}

Sebagai partai pemenang pemilu, wajar jika PDIP optimistis memenangi sebagian besar daerah pada ajang pilkada serentak, akhir 2015 mendatang. Guna menjaga momentum soliditas menjelang kongres, di berbagai daerah digelar berbagai persiapan. Daerah Istimewa Yogjakarta (DIY), misalnya. Optimisme tergambar jika menilik rekam jejak kemenangan PDIP di wilayah ini. Dari lima wilayah di Provinsi DIY, Kota Yogyakarta dan tiga kabupaten dipimpin orang PDIP. Hanya Gunung Kidul yang tidak dikuasai kader banteng. Pada Pilkada kali ini, PDIP berniat menyapu bersih tiga pilkada di DIY yakni di Sleman, Bantul, dan Gunungkidul.

Pada pelaksanaannya, PDIP mengalami kekalahan di tiga pemilihan bupati di Provinsi DI Yogyakarta. Hal itu tercermin dari hasil perhitungan cepat sementara, ketiga calon bupati/wakil bupati yang diusung PDIP kalah. Saat ini proses penghitungan resmi secara bertingkat masih dilakukan. Dikutip dari laman pilkada2015.kpu.go,id, Jumat (11/8), pasangan calon (paslon) yang didukung oleh PDIP di Pilbup Sleman, Yuni Satia Rahayu-Danang Wicaksana (43,73 persen) kalah oleh paslon yang didukung oleh PAN yang koalisi dengan Partai Nasdem, Partai Golkar, PKB, dan Partai Demokrat, yaitu Sri Purnomo-Sri Muslimatun (56,27 persen). Perolehan suara tersebut sudah mencapai 93,19 persen dengan jumlah suara sah 404.959 suara dan partisipasi pemilih sebesar 71,63 persen.

Selain itu, di Pilbup Bantul, paslon incumbent usungan PDIP-Nasdem Sri Surya Widati dan Misbakhul Munir (52,76 persen) kalah juga dari paslon usungan Gerindra-PKB Suharsono-Abdul Halim Muslih (52,76 persen). Data masuk C1 yang sudah ada di KPU mencapai 98,19 persen dengan tingkat partisipasi pemilih mencapai 76,17 persen.

Hal ini berarti dominasi PDIP di Bantul selama tiga periode atau 15 tahun yang telah dikuasainya akan berganti. Senada dengan hal itu, Pilbup di Kabupaten Gunung Kidul pun pasangan yang didukung oleh PDIP Djangkung Sudjarwadi-Endah Subekti Kuntariningsih pun kalah (24,54 persen) dari pasangan yang didukung oleh PAN, Partai Golkar, Partai Hanura, dan Partai Nasdem Badingan-Imawan Wahyudi (39,51 persen). Urutan ketiga diperoleh Benyamin Sudarmadi-Mustangid (23,16 persen), dan urutan keempat diraih Subardi-Wahyu Purwanto (12,79 persen). 


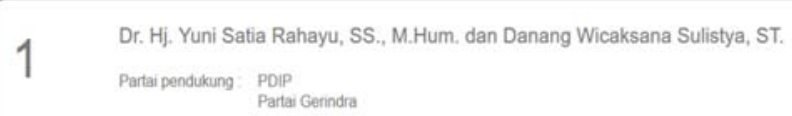

Informasi Kabupaten Sleman

Pemilih dan Pengguna Hak Pilih

\begin{tabular}{|lccc} 
& Laki-laki & Perempuan & Total \\
\hline Penilith & 374.630 & 397.175 & 772518 \\
\hline Pengguna Hak Piinh & 260.343 & 294.974 & 562336 \\
\hline Partisipasi & $69,49 \%$ & $74,27 \%$ & $72,79 \%$ \\
\hline
\end{tabular}

Suara Sah dan Tidak Sah

\begin{tabular}{lrl} 
& & \\
Suara Sah & 516.408 Suara & Prosentase Suara Sah \\
Suara Tdak Sah & 37.599 Suara & $93,21 \%$ \\
\hline Jumlah & 554019 Suara \\
\hline
\end{tabular}

Hasil Hitung TPS (Form C1) Kabupaten Sleman

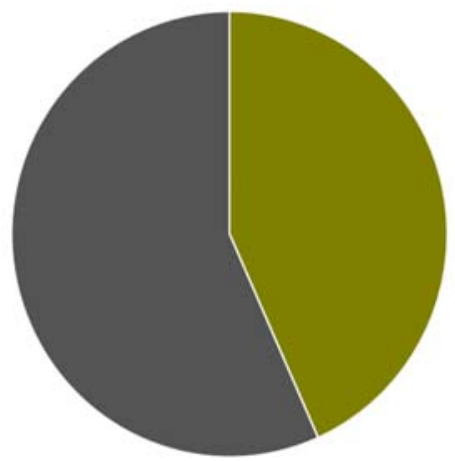

1 Dr Hi Yuni Satia Rahayu, SS, M Hum dan Danang Wicaksana Sulistya, ST Perolehan : 225338 Suara $(43,34 \%)$

2 Drs H Sri Purnomo, M Si dan Dra Hi. Sri Musimatun, M. Kes Perolehan : 294652 Suara $(56,66 \%)$ 


\begin{tabular}{|c|c|c|c|c|c|c|}
\hline \multicolumn{7}{|c|}{$\begin{array}{l}\text { REKAP PEROLEHAN SUARA PILKADA SLEMAN PER KECAMATAN } \\
\text { 9DESEMBER } 2015 \\
\text { DATE PUKUL } 17.40 \text { WB }\end{array}$} \\
\hline \multirow{2}{*}{ NO } & \multirow{2}{*}{ KECAMATAN } & \multicolumn{4}{|c|}{ PASANGAN CALON } & \multirow{2}{*}{ SUARA SAH } \\
\hline & & 1.YUDA & $\%$ & 2. SANTUN & $\%$ & \\
\hline 1 & SLEMAN & 13,658 & 40.69 & 19,907 & 59.31 & 33,565 \\
\hline 2 & TEMPEL & 13,005 & 43.61 & 16,815 & 56.39 & 29,820 \\
\hline 3 & TURI & 8,717 & 42.84 & 11,632 & 57.16 & 20,349 \\
\hline 4 & NGAGLIK & 5,115 & 45.18 & 6,208 & 54.82 & 11,321 \\
\hline 5 & PAKEM & 7,684 & 38.84 & 12,066 & 61.16 & 19,730 \\
\hline 6 & CANGKRINGAN & 7,830 & 46.41 & 9,041 & 53.59 & 16,871 \\
\hline 7 & NGEMPLAK & 13,896 & 46.58 & 15,951 & 53.44 & 29,847 \\
\hline 8 & KALASAN & 15,447 & 40.41 & 22,776 & 59.59 & 38,223 \\
\hline 9 & PRAMBANAN & 10,200 & 38.26 & 16,459 & 61.74 & 26,659 \\
\hline 10 & BERBAH & 12,342 & 45.72 & 14,650 & 54.28 & 26,992 \\
\hline 11 & DEPOK & 17,177 & 48.58 & 18,183 & 51.42 & 35,360 \\
\hline 12 & MLATI & 17,133 & 44.73 & 21,171 & 55.27 & 38.304 \\
\hline 13 & GAMPING & 17,469 & 42.89 & 23,260 & 57.11 & 40,729 \\
\hline 14 & GODEAN & 1,710 & 39.00 & 2,675 & 61.00 & 4,385 \\
\hline 15 & SEYEGAN & 11,119 & 41.21 & 15,860 & 58.79 & 26,979 \\
\hline 16 & MINGGIR & 7,905 & 43.49 & 10,273 & 56.51 & 18,178 \\
\hline 17 & MOYUDAN & 6,570 & 34.40 & 12.527 & 65.60 & 19,097 \\
\hline & JUMLAH TOTAL & 186,957 & 42.84 & 249,452 & 57.16 & 436,409 \\
\hline
\end{tabular}

\section{Perang Pengaruh Media Lokal}

Keterbukaan informasi paska reformasi 1998 melahirkan beberapa efek yang dialami oleh media massa. Salah satunya adalah semakin intensnya media meliput dan memberitakan momentum politik. Era ini menjadi surganya media massa. Mengapa? Karena media massa memiliki kebebasan mencari, mengolah dan mempublikasikan berita. Kebebasan tersebut sebagaimana yang dijamin oleh negara pada pasal 2 UU. No.40 tentang "Kemerdekaan pers adalah salah satu wujud kedaulatan rakyat yang berasaskan prinsipprinsip demokrasi, keadilan, dan supremasi hukum".

Media massa atau bisa disebut sebagai pers memiliki kekuatan membentuk opini publik. Informasi yang disajikan media massa dapat mempengaruhi masyarakat. Sebagaimana dua asumsi Teori dari Ekologi Media. Pertama, media melingkupi setiap tindakan di dalam masyarakat. Kedua, media memperbaiki persepsi kita dan mengorganisasikan pengalaman kita. Berangkat dari dua asumsi tersebut, jelas bahwa media massa memiliki kekuatan mengorganisir atau membentuk persepsi publik. Media memiliki pengaruh besar dalam kehidupan masyarakat.

Media menyediakan informasi berita, hiburan dan pengetahuan bagi masyarakat melalui konten-konten yang diterbitkan. Media adalah agen yang secara aktif menafsirkan realitas untuk disajikan kepada khalayak. (Eriyanto, 2002:26).

Seperti halnya Pilkada serentak yang diselenggarakan pada tanggal 9 Desember 2015. Bantul misalnya, Kekalahan Sri Surya Widati untuk meraih kembali kursi jabatan sebagai bupati dianggap sebagai tumbangnya Dinasti Samawi. Bagaimana tidak, suatu hal 
di luar prasangka, dinasti yang telah berkuasa selama 15 tahun berhasil dikalahkan oleh pasangan Suharsono dan Abdul Halim Muslih.

Kenyataan yang pahit mungkin bagi keluarga Samawi, kedekatan Sri Surya Widati dengan Surat Kabar Harian (SKH) Kedaulatan Rakyat ternyata tidak mampu membawa Sri Surya Widati pada kemenangan seperti periode lalu. Sri Surya Widati dan Kedaulatan Rakyat terhubung secara kekeluargaan. Karena Idham Samawi, suami Sri Surya Widati memiliki hubungan darah dengan pendiri Kedaulatan Rakyat. Dialah M. Samawi, ayah kandung Idham Samawi. Bahkan Idham Samawi kini menjabat sebagai penasehat redaksi Kedaulatan Rakyat.

Lantas bagaimana peran media massa dalam membentuk opini publik. SKH Kedaulatan Rakyat tidak gagal dalam membangun atau mengkontruksi persepsi masyarakat terhadap citra pasangan nomor dua tersebut. SKH di Yogyakarta tidak hanya satu, melainkan banyak. Di sinilah pertarungan wacana antar media massa terjadi dalam memberitakan peristiwa yang sama.

Kalahnya Sri Surya Widati, disebut-sebut karena adanya kader PDIP tingkat ranting yang membelot. Kader-kader tersebut akan dipecat karena dianggap pengkhianat. Tindakan pemecatan disampaikan oleh Ketua DPD PDIP DIY Bambang Praswanto (SKH Sindo, edisi 14 Desember 2015). Bahkan ada ketua ranting, yang rela mengundurkan diri sebagai bentuk pertanggung jawabannya atas kegagalannya memenangkan pasangan calon Sri Surya Widati-Misbakhul Munir.

Edisi yang sama yakni 14 Desember 2015, SKH Kedaulatan Rayat juga menampilkan peristiwa pemecatan kader di PDIP. Berjudul "Kader yang membelot diancam dipecat" wartawan dengan nama pena Awa tidak menyebutkan sama sekali pasangan-pasangan yang kalah Pilkada. Lebih spesifik lagi berita ini ditempatkan di rubrik kawasan Gunung Kidul, sehingga alasan kuat untuk mengaburkan Sri Suryawidati pemilik SKH Kedaulatan Rakyat dari kegagalannya. Wajar bukan Sri Surya Widati tidak disebutkan dalam pemberitaan tersebut, karena spesifik rubrik yang mengulas tentang pemecatan kader PDIP tersebut diulas di kawasan rubrik Gunung Kidul.

Namun jelas tidak dapat dipungkiri, SKH Kedaulatan Rakyat telah mengaburkan dan menonjolkan peristiwa untuk diberitakan. Sebagaimana dikemukakan Entman dalam Analisis Framing. Framing menggambarkan proses seleksi dan menonjolkan aspek tertentu dari realitas oleh media. Framing dapat dipandang sebagai penempatan informasiinformasi dalam konteks yang khas sehingga isu tertentu mendapatkan alokasi lebih besar daripada isu lain.

Framing yang dilakukan SKH Kedaulatan Rakyat tersebut tentunya tidak terlepas dari keberadaan Sri Surya Widati sebagai owner perusahaan SKH Kedaulatan Rakyat. Reese dan Shoemaker (1996: 60) mengungkapkan lima faktor yang mempengaruhi konstruksi di media. Mulai dari faktor individual, rutinitas media, struktur organisasi, kekuatan ekstra media, dan ideologi.

Keberpihakan SKH Kedaulatan Rakyat terhadap Sri Surya Widati semakin jelas dengan berita-berita yang ditampilkan. Misal SKH Kedaulatan Rakyat edisi 10 November 2015 menampilkan dua berita. Pertama berjudul "Sri Purnomo, Badingah dan Suharsono unggul.” Judul tersebut lebih mengulas tentang pemenang pasangan calon di tiga kabupaten DIY. Sebagaimana dikutip dalam SKH Kedaulatan Rakyat "Pasangan calon Sri Purnomo- 
Sri Muslimatun, Badingah-Immawan, dan Suharsono-Abdul Halim Muslih unggul dibandingkan calon-calon lainnya dalam pemilihan umum kepala daerah (Pilkada) serentak di DIY.

Dibandingkan dengan SKH Sindo, SKH Sindo lebih berani mengungkap kekalahan Sri Surya Widati dan keterkaitannya dengan PDIP. Seperti judul "PDIP Terlalu Percaya Diri” pada edisi 11 Desember 2015. Gambar Suharsono dan Sri Surya Widati ditampilkan dengan dukungan suara yang diperoleh masing-masing keduanya. Bahkan catatan dalam berita tersebut menyatakan "Alasan pertama bisa jadi karena masyarakat Bantul sendiri sudah tidak menginginkan keluarga Idham Samawi untuk berkuasa.”(SKH Sindo, edisi 11 Desember 2015).

\section{Lemahnya Komunikasi Internal}

Ketua Partai Demokrasi Indonesia (PDIP) Daerah Istimewa Yogyakarta, Bambang Praswanto, mengaku bertanggung jawab atas kekalahan partai itu dalam pilkada di tiga kabupaten yang digelar serentak pada 9 Desember 2015. Dia bahkan siap diadili pimpinan partainya dalam forum Rapat Kerja Nasional (Rakernas) di Jakarta pada 10-12 Januari 2015.

“Dalam Rakernas PDIP di Jakarta, saya siap mempertanggungjawabkan hasil pilkada serentak di Yogyakata”

Praswanto berterus terang ada kesalahan strategi saat Pilkada Kabupaten Bantul, Pilkada Kabupaten Gunungkidul, dan Pilkada Kabupaten Sleman pada 9 Desember 2015. Maka perlu perubahan strategi untuk pilkada serentak pada 2017.

Masalah lain yang menjadi penyebab kekalahan PDIP Yogyakarta, Praswanto mengakui, yakni dinamika politik internal partai yang dipimpinnya. Akibatnya, PDIP memang tak solid, meski seyogyaanya semua kader mematuhi semua keputusan Partai.

"Bagi kader yang tidak patuh maka perlu diingatkan untuk kembali ke jalan Partai.

Namun, jika tidak, akan diusulkan untuk dipecat, dan beberapa nama kader yang membangkang sudah diusulkan untuk dipecat”

Meski rekomendasi pemecatan sejumlah kader telah diusulkan kepada pimpinan pusat PDIP di Jakarta, usulan itu belum disetujui sampai sekarang.

"Termasuk pemecatan dari lima orang relawan Jas Merah yang merupakan kader PDIP, juga belum turun"

Tiga pasang calon yang diusung PDIP untuk Pilkada di Kabupaten Bantul, Kabupaten Gunungkidul, dan Kabupaten Sleman tak satu pun yang memang. Pasangan Sri Suryawidati-Misbakhul Munir yang diusung PDIP di Pilkada Bantul kalah dari pesaingnya, Suharsono-Abdul Halim. Pasangan Djangkung Sudjarwadi-Endah Subekti yang diusung PDIP untuk Pilkada Gunungkidul tak bisa menandingi pasangan petahana BadingahImmawan Wahyudi.

Pasangan Yuni Satia Rahayu-Danang Wicaksana yang diusung PDIP dan didukung Gerindra dan PKS untuk Pilkada Sleman tak sanggup mengalahkan pasangan calon Sri Purnomo-Sri Muslimatun. Ketua Panitia Pengarah Rakernas PDIP, Eva Kusuma Sundari, menegaskan bahwa forum itu tidak akan membahas atau mengevaluasi penyelenggaraan 
pilkada serentak 9 Desember 2015. Rakernas itu akan membahas pemenangan pilkada serentak pada tahun 2017.

"Untuk evaluasi pilkada sudah dilakukan di masing-masing daerah"

\section{Kegagalan Propaganda PDIP}

Dalam melakukan komunikasi politik guna meningkatkan pencitraan diri dan partainya maka PDIP memerlukan sebuah penanaman opini pada masyarakat bahwa individu politis dalam hal ni adalah calon kepala daerah yang diajukan oleh PDIP benarbenar merupakan personal tepat untuk menjadi figur yang dapat menganyomi masyarakat. Posisi Yuni yang notabane merupakan wakil bupati Sleman seharusnya mampu memenangkan pertarungan opini tersebut, ditambah lagi dengan latar belakang Yuni yang memiliki banyak pengalaman dalm bidang advokasi sejak jauh sbelum dia menjabat.

Namun kenyataannya adalah sinar Yuni terhalang oleh wujud Sri Purnomo yang terlalu dominan selama mereka berdua tampil sebagai pasangan dalam kurun waktu lima tahun terakhir. Seharusnya Yuni dan tim PDIP mampu memanfaatkan isu-isu seperti Sri Purnomo yang tidak pro rakyat kecil dengan menjamurnya took modern selama dirinya menjabat, dan hal itu sudah menjadi rahasia umum. Namun sepertinya tim PDIP gagal untuk menggoreng isu tersebut untuk menurunkan kredibilitas Sri Purnomo.

Ada beberapa hal yang menjadi catatan kenapa isu tersebut gagal digoreng oleh tim PDIP; Pertama ketidakmampuan tim dari PDIP untuk mengolah isu ini karena berfikir dikarenakan hal tersebut sudah menjadi rahasia umum maka tidak perlu lagi direkayasa secara politis, jadi PDIP memasrahkan isu tersebut bergulir secara alami. Kedua adanya kekhawatiran dari tim bahwa nantinya isu tersebut jika terlalu ditonjolkan akan menjadi senjata makan tuan mengingat selama lima tahun terakhir tokoh yang mereka usung merupakan pasangan Sri Purnomo dalam menjalankan roda pemerintahan di Sleman.

Hingga pada akhirnya jadi lah Sri Purnomo aman dari politisasi isu bahwa dirinya merupakan sosok yang tidak pro rakyat kecil, dan otomatis sinar Yuni yang memiliki banyak pengalaman dalam hal advokasi kerakyataan tertutup oleh kebaikan dan prestasi Sri Purnomo yang digemborkan oleh tim suksesnya.

Disini dapat kita lihat betapa lemahnya peran manajemen opini publik tim politik PDIP padahal Dan Nimmo $(1982,14)$ mengatakan bahwa Politisi sebagai komunikator politik memainkan peran sosial yang utama, terutama dalam pembentukan opini publik. Maka politisi atau politikus berkomunikasi sebagai wakil suatu kelompok dan pesan-pesan politikus itu adalah untuk mengajukan dan atau melindungi tujuan kepentingan politik. Artinya komunikator politik mewakili kepentingan kelompok, sehingga jika dirangkum maka politikus mencari pengaruh melalui komunikasi sebagaimana sifat para praktisi Public Relations.

Selain hal tersebut pencitraan positif terhadap diri Yuni dinilai tidak terlihat muncul ke permukaan, padahal pencitraan positif yang kuat dalam diri seorang politisi sangat lah penting untuk meraih dukungan khusunya dari para swing voter mengacu pada pendapat Onong Uchjana (2007:27) yang mengatakan bahwa seorang komunikator yang populer akan dapat lebih mudah memberikan pengaruh ketika berkomunikasi.

Pengaruh tersebut amat dibutuhkan dalam menjalankan fungsi humasnya, seorang politisi harus dapat menjalankan komunikasi politik dengan baik, dan baik tidaknya 
komunikasi politik tersebut amat dipengaruhi oleh opini publik (Dan Nimmo, $2000: 29$ ). Dalam pembentukan opini publik tersebut, seorang politisi (komunikator) diperkenankan melakukan berbagai propaganda untuk mencapai tujuannya, sebab propaganda dapat membuat sang komunikator memperoleh respon dari komunikan (masyarakat) yang membuat komunikan makin dekat dengan tujuan sang komunikator (Dan Nimmo, 2001 : 44).

Pendapat dari Nimmo itu makin diperkuat dengan keyakinan bahwa seandainya propaganda tersebut dilakukan secara terus menerus berulang-ulang maka jangankan citra dan pandangan positif dari komunikan (masyarakat) yang didapat, sebuah kebohongan pun akan menjadi sebuah kebenaran.

Agar propaganda yang dilakukan oleh komunikator, sukses mengontrol komunikan maka perlu menggunakan strategi-strategi sebagai berikut; (1) koersif, yaitu dengan memberikan rasa takut dalam diri komunikan, (2) persuasif, metode ini menimbulkan efek sang komunikan akan melakukan secara suka rela apa-apa yang diarahkan oleh komunikator, dan yang terakhir (3) parvasif, metode ini adalah proses penyampaian pesan secara berulang-ulang pada para komunikan. Dimana ketiga strategi tersebut pada ujungnya akan menggiring komunikan mengikuti kemauan komunikator. Namun sekali lagi, tim dari PDIP tidak melakukan propaganda seperti itu pada Sri Purnomo dan tim pengusungnya, mereka malah sibuk bermain dalam ranah administrasi dengan tidak mengeluarkan surat izin pada kader PDIP yang menjadi pasangan Sri Purnomo. Alih-alih mengejar simpati rakyat, mereka malah berhrap menjadi pasangan tunggal dan menang melawan kotak kosong. Perilaku ini yang kemudian menjadi cerminan bahwa PDIP menciderai demokrasi di Sleman.

\section{Kegagalan Mengelola Media Baru dan Menarik Suara Kaum Muda}

Kaum muda yang dimaksudkan di sini adalah kaum muda yang oleh Henry Milner dikatakan sebagai generasi internet (Milner, 2010: 34). Yang di Amerika adalah generasi yang dilahirkan pada dekade tahun 1970-an, dan kalau di Indonesia adalah generasi yang dilahirkan pada dekade tahun 1980-an.

Kaum muda dari kalangan mahasiswa memiliki karakteristik, spesifikasi dan kedudukan yang berbeda dari kalangan kaum muda pada umumnya. Kaum muda dari kalangan mahasiswas memiliki kapabilitas intelektual yang secara tradisional menjadi sumber inspirasi pergerakkan serta menjadi penggerak dan agen perubahan dalam masyarakat. Selain itu, kaum muda dari kalangan mahasiswa dipandang lebih rasional dan memiliki daya kritis yang lebih tinggi dari kalangan kaum muda pada kelompok lainnya, sehingga diharapkan dapat memberikan pandang- an yang lebih objektif. Dan terakhir, kaum muda dari kalangan mahasiswa pada umumnya memiliki kepedulian yang lebih tinggi terhadap berbagai isu-isu kemasyarakatan dibandingkan dengan kaum muda dari kalangan lainnya.

Hal ini mengukuhkan paradigma generasi internet sebagaimana yang dikemukakan Milner bahwa generasi yang tumbuh atau berkembang bersama internet. Intensitas berinteraksi dengan internet terus bertambah seiring dengan meningkatnya kebutuhan akan informasi terkait dengan peningkatan kapasitas intelektual dan kebutuhan aktualisasi diri melalui peningkatan penguasaan informasi. Hal ini ditunjukkan dengan semakin 
banyaknya alokasi waktu yang digunakan untuk berinteraksi melalui penggunaan internet dibandingkan dengan alokasi waktu penggunaan media-media lainnya.

Sikap politik dalam hal ini dapat dimaksudkan sebagai sikap politik terhadap internet itu sendiri sebagai media baru pembawa informasi, sikap politik terhadap isu-isu yang disampaikan yang dalam hal ini adalah isu-isu politik kontemporer, dan sikap terhadap konstelasi politik nasional terkait dengan pemilihan umum dan Pilkada. Sebagaimana telah dikemukakan dalam logik teoritik di atas, sikap merupakan hasil internalisasi dari suatu stimulus yang diterima dan telah melalui serangkain proses mental pada diri seseorang sehingga menghasilkan sikap tertentu terhadap stimulus tersebut. Hal ini mengisyaratkan adanya suatu perhatian terhadap stimulus itu agar dapat diterima dan menjalani serangkaian proses mental sehingga menghasilkan sikap.

Perhatian terhadap isu-isu politik kontemporer oleh kaum muda dari kalangan mahasiswa dapat dikatakan cukup tinggi. Keempat kaum muda dari kalangan mahasiswa ini cukup intens dalam mengikuti dan memberikan perhatikan terhadap perkembangan isuisu politik kontemporer di internet. Dengan alasan-alasan tertentu, fokus perhatian terhadap isu-isu politik kontemporer memiliki titik tekannya sendiri-sendiri.

Hampir semua isu politik yang ditampilkan di internet menyita perhatiannya. karena internet tidak hanya menyampaikan sebuah berita atau isu politik, akan tetapi internet juga memberikan sisi yang lebih banyak dari suatu pemberitaan dengan cara penyampaian yang cenderung berbeda sehingga dapat memberikan informasi tambahan.

Beragamnya isu-isu politik nasional yang menjadi perhatian kaum muda dari kalangan mahasiswa ini menunjukkan kepedulian kaum muda terhadap berbagai isu atau persoalan yang dihadapi masyarakat dan bangsanya. Namun bagaimana sebenarnya kaum muda merespon isu dalam benaknya, hal itu terkait dengan proses mental di dalamnya.

Keberadaan internet merupakan suatu yang tidak terhindarkan, dan merupakan suatu keharusan zaman. Perannya sebagai media informasi dari waktu ke waktu mengalami perkembangan yang sangat signifikan dalam menggantikan/mengambil peran media-media lain yang terlebih dahulu ada. Dalam satu dekade telah mampu menggeser peran majalah, film dan radio sebagai media informasi. Dalam waktu yang tidak berapa lama, kemungkinan peran televisi dan surat kabarpun akan mengalami pergeseran pula, diambil alih oleh internet.

Dalam memenuhi kebutuhan akan informasi, internet menjadi media utama yang mampu mengakomodir seluruh tuntutan kebutuhan informasi penggunanya melalui berbagai bentuk dan jenis informasi dengan ragam perspektif. Sumber-sumber informasi yang diakses memiliki keragaman sesuai dengan kebutuhan masing-masing pengguna, namun secara keseluruhan terdapat satu kesamaan aktifitas dalam pencarian informasi yakni aktifitas pencarian informasi yang berkaitan dengan pengetahuan, berita dan jejaring sosial melalui website ilmu pengetahuan, website pemberitaan dan media sosial (facebook, Twitter, email).

Motif pencarian informasi dan keasyikan dalam menelusuri informasi pada umumnya adalah ekstase kepuasan dalam mencari dan memperoleh informasi tersebut yang digunakan untuk perubahan, kebebasan berpikir, aktualisasi diri, dan membantu kegiatan menjadi lebih efisien dan efektif. Ini merupakan motif gratifikasi dari penggunaan 
internet yang dapat diidentifikasi. Termasuk di dalamnya adalah informasi-informasi yang terkait dengan isu-isu politik terkini yang terjadi di tanah air.

Pengguna pada umumnya cukup intens dalam mengikuti pemberitaan tentang isuisu politik terkini dan memiliki pengetahuan yang cukup tentang isu-isu politik terkini. Tetapi dalam menanggapi isu-isu politik terkini tersebut, para pengguna memiliki perbedaan dalam menerima, memahami dan menyikapinya. Khusus pada pemberitaan yang terkait dengan isu-isu politik terkini, pada umumnya pengguna menunjukkan sikap bosan, muak dan cenderung sebel, karena kasusnya hampir sama yakni kasus tentang korupsi dan pemerintah yang cenderung lambat atau kurang responsif dalam menyikapi berbagai persoalan yang dihadapi, sehingga menimbulkan sikap skeptis pada kaum muda dari kalangan mahasiswa yang diteliti terhadap konstelasi politik nasional khususnya untuk pemilu, Pilkada dan kepemimpinan nasional. Terhadap internet sendiri sebagai media baru, pada umumnya disambut dengan sikap positif meski diterima secara kritis, dan pengaruh internet dipandang dominan dalam membentuk pandangan dan sikap kaum muda tehadap berbagai masalah yang menjadi perhatian mereka.

Jika kita menelisik geliat tim PDIP di media social, tampak tidak ada upaya yang serius untuk memenangkan pasangan yang mereka usung di kabupaten Sleman. Terlihat secara kasat mata yang paling banyak muncul untuk menyapa konstituen yang mayoritas di dominasi oleh anak muda itu adalah sang kompetitor yang kerap muncul baik dengan akun official media social mau pun web berbayar yang diluncurkan secara terencana.

\section{E. SIMPULAN}

Adapun kesimpulan, yang bisa peneliti ambil dalam menganalisis kegagalan komunikasi politik PDIP dalam Pilkada Serentak di Sleman tahun 2015 lalu, adalah sebagai berikut:

1. Kurang kuatnya komunikasi internal di PDIP. Komunikasi tentu menjadi hal yang penting di tubuh partai politik. Adanya koordinasi antara satu aktor politik dengan yang lainnya tentu akan mensolidkan tubuh partai tersebut. Hal inilah yang menurut analisis peneliti perlu untuk dilakukan PDIP dalam Pilkada-Pilkada selanjutnya, mengingat dalam Pilkada Serentak di Sleman lalu, beberapa kali peneliti menemukan adanya perbedaan jawaban/pendapat dari para elite PDIP sendiri.

2. Tidak adanya permainan isu dari PDIP untuk menarik perhatian masyarakat. Isu menjadi sebuah hal yang mampu menarik opini publik. Ada beberapa isu yang bisa dimainkan untuk menjatuhkan kompetitor, seperti: ketidak berpihakan kepada rakyat kecil, pembangunan kota yang tidak tertata yang bisa dimainkan PDIP, namun PDIP ternyata tidak melirik hal tersebut.

3. Kurangnya pemanfaatan media social. Media social mempunyai pengaruh yang besar, terutama untuk menarik perhatian khalayak muda. Namun PDIP juga kurang memanfaatkan ini dengan baik, terbukti sedikit sekali postingan-postingan di media sosial terkait dengan calon Bupati yang diusung PDIP ini.

4. Kurang optimalnya publisitas di media koran. Koran masih menjadi media yang cukup strategis untuk menarik perhatian masyarakat, terutama pada khalayak tua 
dan masyarakat menengah ke bawah yang kurang melek terhadap media baru. Namun lagu-lagi pemberitaan di koran mengenai figur calon Bupati PDIP ini juga sangat terbatas.

\section{DAFTAR PUSTAKA}

Cangara, Hafied. (2011). Komunikasi Politik, Konsep, Teori, dan Strategi. Jakarta: Grafindo.

Djamaluddin, Deddy. (2004). Komunikasi Persuasif. Bandung: Remaja Rosdakarya.

Effendy, Onong Uchana. (2001). Dinamika Komunikasi. Bandung: Remaja Rosdakarya.

Fiske, John. (1990). Cultural and Communication Study. Jakarta: Jalasutra.

Graber, Thomas. (1984). The News: How People Tame The Information Tide. Longman.

Harun, Rochajat dan Sumarno. (2006). Komunikasi Politik Sebagai Suatu Pengantar. Bandung: Bandar Maju.

Kamarudin, Ahmad. (2004). Partai Politik dan Transisi Demokrasi. Bandung: Remaja Rosda Karya.

Moleong, J. Lexy. (2000). Metode Penelitian Deskriptif. Bandung: Penerbit Remaja Rosdakarya.

Muhtadi, Asep Syaiful. (2008). Komunikasi Politik. Bandung: Humaniora.

Nimmo, Dan. (1993). Komunikasi Politik. Jakarta; Gramedia.

Prida A.A.A, S.Sos. (2007). Public Relations (PR), dan Kesalahpahaman Publik Atas Pemaknaan Sebuah Profesi. Jurnal Ilmiah SCRIPTURA (Vol. 1 No 2 Juli 2007). ISSN 1978-385X.

Yacub, M. Dahlan. (2001). Kamus Sosiologi Antropologi. Surabaya: Indah. 